\title{
AFRICAN-AMERICAN FEMALE STEREOTYPING IN THE SECRET LIFE OF BEES
}

\author{
Carolina Pallín López \\ Universidad de las Islas Baleares \\ carolina.pallin@uib.es
}

\section{AbSTRaCT}

The film that is being analyzed in this article, The Secret Life of Bees, offers a unique piece to work on. This motion picture is based on Sue Monk Kidd's novel with the same title published in 2003, and was directed by one of the very few African-American women directors, Gina Prince-Bythewood. This story puts forth an unusual depiction of the way African-American women have traditionally been portrayed. One of the key elements that contributes to this rare representation is the «Magical Negro» character in the movie, which has a tradition of being represented by men.

The aim of this article is to analyze the way the «Magical Negro» character (August Boatwright) is introduced in The Secret Life of Bees, together with the other female characters (Lily Owens, Rosaleen Daise, June Boatwright and May Boatwright). I will also analyze how these representations contribute or shatter female African-American stereotypes. This film introduces a wide range of icons that go from the illiterate slave to the independent business owner, offering in this way a great piece to examine. This article will constitute an interdisciplinary inquiry which will take into account Gender Studies, Stereotyping, Cultural Studies and African American Studies.

KeY WORDS: African-American, Gender, Stereotyping, Culture.

\section{RESUMEN}

El filme que se analiza en este artículo, The Secret Life of Bees, nos ofrece una obra única para examinar. Dicha película está basada en la novela con el mismo título escri- 
ta por Sue Monk Kidd, publicada en 2003, y dirigida por una de las pocas directoras afroamericanas, Gina Prince-Bythewood. Esta historia nos muestra una imagen inusual de la mujer afroamericana si se compara con la forma en que tradicionalmente se ha escenificado dicho colectivo. Uno de los elementos clave que contribuye a tal representación es el personaje «Magical Negro» en la película, el cual tradicionalmente ha sido personificado mediante personajes masculinos.

El objetivo de este artículo es analizar la forma en que el personaje «Magical Negro» (August Boatwright) es presentado en The Secret Life of Bees junto con el resto de personajes femeninos (Lily Owens, Rosaleen Daise, June Boatwright, May Boatwright). También analizaré las formas en que tales iconos contribuyen o crean una ruptura con respecto a los estereotipos femeninos afroamericanos. Esta cinta muestra una amplia gama de representaciones que van desde la esclava analfabeta hasta la mujer independiente dueña de su propio negocio, ofreciéndonos de esta forma una obra excepcional con la que trabajar. El presente artículo constituye un estudio interdisciplinar que tendrá en cuenta los estudios afroamericanos, de género, de estereotipia y culturales.

Palabras Clave: Afroamericanos, Género, Estereotipia, Cultura.

\section{INTRODUCTION}

The film that is subject to analysis here, The Secret Life of Bees, is based on the best-selling novel with the same title written by Sue Monk Kidd and published in 2003. The story is portrayed in the South Carolina of 1964, while the Civil Rights Movement was taking place. This 2008 movie presents a faithful account of the historical events and social situations described in the book, which, in fact, were happening during that period of time (an example of this is the scene in which Rosaleen and Lily are watching the real July $2^{\text {nd }} 1964$ television scene of the announcement of the Civil Rights Act, stating the following: «It does say that there are those who are equal before God shall now also be equal in the polling booths, in the classrooms, in the factories and in hotels and restaurants and movie theaters»), while at the same time creating a fictional safe haven, the so-called «pink house», for African-Americans and specially for the Boatwright family during that time. As Gina Prince-Bythewood (the director) said to the book's author, «What I want to do is to honor your voice, and then my voice as a scriptwriter and stay true to this story.» The author mentions in the Special Features section of the DVD, in which she has the opportunity to explain her direct involvement in the creation of the movie, that she grew up in the South of the United States of the 60's, and that while researching she found out that «there were African-American families at that time who had property and education, but were never written about». With her book she wanted to represent this other reality that, although rare, did exist.

The film narrates the story of a fourteen-year-old white girl, Lily Owens, who lives in a peach farm with her father. She decides to leave the farm to go to Tiburon, SC, searching for more clues about her late mother, whom she accidentally killed at the age of four, and also to escape from her bitter and cruel father. She flees with her caregiver and friend, Rosaleen Daise and, once there, they are taken in by August Boatwright and her sisters June and May. There, they will discover a different world, new to them, that will surround 
them with love, friendship and respect. Their lives will be forever changed. They now will be able to imagine and see events they never thought could happen come true.

In this article I intend to analyze probably the only movie directed by an AfricanAmerican woman that has a «Magical Negro» female as one of the main characters. The term «Magic/Magical/Mystical Negro» emerged in 1958 with Stanley Kramer's The Defiant Ones. The definition that I have reached for the term «Magical Negro», after watching several films in which we find such character, is that of the black character (most likely a man) that guides to the right path, helps or takes care of the white protagonist (also a man, in most cases), even making use of mysterious or supernatural powers. My goal is to see how her vision -and therefore the representation of such character- is when it comes to the topic of African-American stereotyping. I will also pay attention to the way the «Magical Negro» female character interacts with the rest of the characters in the film, both black and white.

The following analysis will be done with the aim of finding evidence to support the following hypotheses:

1. That the director's gender, as well as the nationality, can affect directly the representation of the «Magical Negro» character.

2. That such character will be built differently, depending on its own sex and/or cultural gender («Magical Negro» man or woman, male or female).

\section{THEORETICAL BACKGROUND}

The reading of bell hook's Feminist Theory: From Margin to Center offered me so many «Aha» moments. It put words and dissected so many thoughts I had had before; and it also gave me a new understanding of the reality of women of color both back in the day and, sadly, still today. There, I was able to identify so many statements I could directly link and relate to the film. An example of this is the explanation hooks offers of margin and center at the beginning of the book which, to me, is clearly represented in The Secret Life of Bees (though with some significant differences). In the film, we find the margin represented by the "pink house» (the house where the Boatwright sisters cohabit); there, we are the witnesses of a different world made up of self-employed, independent, educated and loving African-American women (Rosaleen: «I guess I never meet negro women like them neither. How much land she said they got? [...] It's like he's got his own spot in the world, where the outside don't come in»). They live in the margin and they are happy to do so, the margin offers them a safe environment where they are able to be themselves, to be free. This margin introduced here radically differs from the margin hooks explores: «We could enter that world, but we could not live there. We had always to return to the margin, to beyond the tracks, to shacks and abandoned houses on the edge of town» (hooks, 1984: xvi). So, in essence hooks presents a margin with profound negative connotations, while Prince-Bythewood's margin is switched around, offering us one with distinctly positive connotations.

In her book, bell hooks strongly criticizes white feminists (like Friedan's The Feminine Mystique) who did not see the bigger picture, the ones who thought, and may still think, that the most important issue concerning feminism is gender, while they forget 
about two other key elements: class, and most importantly for us in this analysis, race. Following there is an excerpt taken from hook's Feminist Theory: From Margin to Center quoting Leah Fritz's 1979 Dreamers and Dealers discussion of the women's movement going on at that time, which deeply struck me:

Women's suffering under sexist tyranny is a common bond among all women, transcending the particulars of the different forms that tyranny takes. Suffering cannot be measured and compared quantitatively. Is the enforced idleness and vacuity of a «rich» woman, which leads her to madness and/or suicide, greater or less than the suffering of a poor woman who barely survives on welfare but retains somehow her spirit? There is no way to measure such difference, but should these two women survey each other without the screen of patriarchal class, they may find a commonality in the fact that they are both oppressed, both miserable (hooks, 1984:4).

Making use of the film that is being subject of study as a clearer and visual example to refute the above quotation, we could ask ourselves: can Rosaleen's suffering be compared to August's or June's? No, it can't. Although they are all women and black, the fact that Rosaleen is enslaved and barely educated puts her in a far from equal position compared to the Boatwright's sisters. Can Rosaleen's suffering be compared to Lily's? In the same way, it can't, because, in addition to the racial difference which offers Lily too many privileges that Rosaleen can't even dream of, at the end of the day Rosaleen is there to serve and take care of Lily. Therefore, I conclude that suffering can and should be measured and, in this specific case, Rosaleen's suffering is far greater compared to the suffering the Boatwright sisters or Lily may endure. «Being oppressed means the absence of choices» (hooks, 184: 5).

With this film we ascertain a way of representing African-Americans that differs from the pattern or trend we are generally exposed to in the media, as bell hooks describes in Black Looks: Race and Representation:

If we compare the relative progress African Americans have made in education and employment to the struggle to gain control over how we are represented, particularly in the mass media, we see that there had been little change in the area of representation. Opening a magazine or book, turning on the television set, watching a film, or looking at photographs in public spaces, we are likely to see images of black people that reinforce and reinscribe white supremacy (hooks, 1992: 1).

In The Secret Life of Bees, although I can identify some black stereotypes, I am also able to see the effort from the director's side to try to avoid such representations. As indifferent as it may appear to some people not familiar with African-American history and/or culture, the fact that what is presented to us in this film is a group of women cohabiting by themselves, independent from any man, running their own business and that, on top of that, this group of women are black, is highly remarkable, always taking into account the time in history the film is framed in. One example of the director's effort to elude stereotyping is the case of Rosaleen. In the Special Features section of the DVD, it is explained that the character of Rosaleen is actually older in the book, but PrinceBythewood thought that having a younger Rosaleen would keep her away from the old nanny/mammy stereotype. 
Although in 1964 African-Americans were supposed to be free and equal, their reality was still far from that, especially in the South. As Joly states in La interpretación de la imagen: Entre memoria, estereotipo y seducción, «Si los estereotipos y los tópicos logran imponerse es porque, a su manera, expresan los valores del contexto sociocultural en cuyo seno se inscriben» (Joly, 2003: 224). In other words, although society is supposed to change, it still remained patriarchal, sexist and, overall, racist. In the early 60's we could still find all kind of images and items that reinforced black stereotypes. These items and images referred to as black collectibles were «items made in or with the image of an African-American [...]. They were almost universally derogatory, with exaggerated racial features that helped to «prove» that, indeed, African-Americans were not only different but inferior as well» (Goings, 1994: xiii).

The two recurring images in the film, which are actually connected to each other, offer us a completely different vision of the African-American woman compared to the one that was being projected back in the early 60's in the US. On the one hand, we have the icon that is very dear to Lily, and that will eventually guide her to the Boatwright's home: that of the black Virgin Mary holding a black Jesus. This drawing was used by the Boatwright sisters in the label of the honey jars that were sold all over the town (both in the center and the margin, for both black and white folks). This icon is as unique as the women behind it, and it breaks with the stereotyping African-American women, as well as men, endured for more than four centuries. We have a very detailed description offered by Kenneth Goings in his Mammy and Uncle Moses: Black Collectibles and American Stereotyping of the way African-American women were portrayed by white people from around 1880 until the early 1960's:

African-American women were generally cast as little pickaninnies or as mammies. While portrayed in various age ranges, they are generally all servants in the Aunt Jemima mold- fat, deferential, but happy. These depictions of black women date back to antebellum days. African-American women had always been portrayed as unattractive, distinctly nonfeminine, and lacking in most qualities associated with womanhood, with the notable exception of birthing- there they were seen as womanly par excellence. African-American women were never angry (except toward their no-account husbands), or even physically tired. They were always smiling, content with their lot in life, and happy to be working for their «massa» (Goings, 1994:14).

On the other hand, the carved figure that is somehow the center of «the pink house» world, and also the reason behind the portrait of the black Virgin Mary in the honey jar labels, is the wooden black Madonna that is in the "pink house's» parlor. This figure is not only worshiped by the Boatwright's sisters, but also by the group of women called «Sisters of Mary», who meet in the «pink house» every Sunday. This is another element that connects both August and Lily (apart from the bees, having the color blue as their favorite, and of course Deborah, Lily's mother); they both have an spiritual connection with her (one example of this can be seen in the scene in which Lily faints when she sets her hand on the black Madonna touching her heart; in that scene even June can feel the connection between Lily and the black Madonna) that at the same time connects these two characters to such level that makes them find each other against all odds. In contrast to the previous quotation, the image offered by the black Madonna presents us a black 
woman with her right hand in the air making a fist. Her face is calm, strong and sweet, while at the same time revealing an intense reflection in her eyes of the pain endured by African-Americans.

With August Boatwright, our female «Magical Negro» character in the film, we are able to perceive a clear evolution that breaks with the stereotypical image of the black female portrayed during that period of time. As the movie progresses we learn that August was Lily's mom (Deborah) caregiver. This is something that makes August experience an amalgamation of feelings about her relationship with Deborah. Yes, she did love her, but, at the same time, the role she played as the nanny/mammy/caregiver of Deborah did nothing to rupture with the stereotypical image of black women while degrading her to the lowest level in the ladder of social hierarchy. Because of this, August couldn't help but to dim the honest love she felt for Deborah. The memory of herself embracing the African-American female stereotypical representation made the so longed for «new Negro» icon be dispelled. «The «new Negroes» were younger African-Americans who were going to resist the old stereotypes of the past, and they were going to be unstinting in their demands to be treated as equals. This militancy was displayed in various ways, such as the support given to the NAACP and other racial protest organizations» (Goings, 1994: 24). This is also the reason why June (the only character representing the «new Negro» image to its full potential in the film) is so reluctant to accept and, somehow, so bitter towards Lily at the beginning. She cannot come to terms with the idea that her beloved sister, her family's matriarch, once became the depiction of the derogatory conception white people had of African-American women. As hooks explains in Feminist Theory: From Margin to Center:

Past feminist refusal to draw attention to and attack racial hierarchies suppressed the link between race and class. Yet class structure in American society has been shaped by the racial politic of white supremacy; it is only by analyzing racism and its function in capitalist society that a thorough understanding of class relationships can emerge. Class struggle is inextricably bound to the struggle to end racism (hooks, 1984: 3).

Through August Boatwright we are taken to the journey too many African-American women endured from the stereotypical image of the mammy/nanny to the fight to become and hold their place as the «new Negro». The way I see it, with the «pink house» haven and its inhabitants (especially with August), the director's purpose is the portrayal of a reality opposite to the factual one going on during that period of time, the patriarchal-phallocentric system (there is even a scene that I interpret as ridiculing phallocentrism, in which May brings a very particular banana dessert to Lily and Zach, making both adolescents break into laughter). A system that, as we can observe in the following quotation, still depends on the woman herself to make any possible sense:

The paradox of phallocentrism in all its manifestations is that it depends on the image of the castrated woman to give order and meaning to its world. An idea of woman stands as linchpin to the system: it is her lack that produces the phallus as a symbolic presence, it is her desire to make good the lack that the phallus signifies (Mulvey 1989:14).

The August we witness in the film does not embody the castrated woman. She once played a role in the endocentric world (while she worked for Deborah's family) and was 
marked by the social stigma, but not anymore. She is an independent woman who is single by choice, who takes care of her family, and who runs her own business. No man is needed in the «pink house» world; the phallus is outside their world.

\section{ANALYSIS}

After watching The Secret Life of Bees it becomes clear that the «Magical Negro» character representation offered in this film differs drastically from what we have traditionally been exposed to in films like Ghost, The Green Mile or The Legend of Bagger Vance, just to mention some examples.

The character presented in this film clashes in some aspects with the definition of the «Magical Negro» given previously in this article: «the black character (most likely a man) that guides to the right path, helps or takes care of the white protagonist (also a man, in most cases), even making use of mysterious or supernatural powers». First of all, August Boatwright is a woman. This fact breaks with the phallocentric idea embedded in the representation of such character; and that actually supports the patriarchal system in which the man is in charge of the fate of the ones surrounding him. Second of all, she is not guiding or taking care of a man, but of a teenage white girl; and not only does she take care of this girl, but of all the people surrounding her, both black and white. She is the most balanced of the characters in the film; she carries a little bit of each one inside of her. Somehow, we could state that she is the living representation of the black Madonna that everybody respects and loves in the «pink house.» With all this, August Boatwright's character discourages and ostracizes the stereotypical image we had of the «Magical Negro» character, making us see it from a new perspective that collides with the norm.

Another aspect August Boatwright's character breaks with is the one concerned with the reinforcement of the African-American female stereotypes. Although the action of the film takes place in the context of the 1960's in the US, we barely see any of the stereotypical images that were characteristic up to around that time (the mammy/ nanny caregiver that was always happy to serve). The «Magical Negro» female character analyzed here embodies an educated, single by choice (we can see that in the scene in which Lily asks August if she had ever been in love, and August replies: «Of course I was [...], I loved him enough. I just loved my freedom more»), successful business owner that does not have children, rupturing this way with the stereotype that portrays AfricanAmerican women constantly giving birth. Although we learn about the fact that she used to take care of Lily's mom, we never see any images of that period of her life. The only August we witness is the one disconnected from the stereotypical images. I believe that the year in which the movie was released has a lot do it with it, together with the fact that the director is an African-American woman. In 2008, with the election of Barack Obama, the first African-American man in the history of the United States to become President, a sense of hope spread, supporting the fact that things are changing little by little, leaving behind, although never forgetting, all the different kinds of oppression, disrespect, and pain endured by the African-American community. 
In my view, the relationship between August and Lily starts long before they physically meet each other. They have a special kind of «magical» connection (that they are not aware of at the beginning of the film) that unites them. The bees that Lily starts seeing in her room constitute the beginning of their connection; they are a sign that August unconsciously sends Lily in an effort to guide her home, where she truly belongs to (Lily: «I feel like I'm were I'm supposed to be. I really do. I just need some time to figure out why...»). In fact, in one of the scenes a bee is walking on the map almost pointing at the town of Tiburon, SC, the city where Lily will end up fleeing to with Rosaleen. Once Lily gets to «the pink house», August emerges as her protector and defender. We could even say, symbolically speaking, that she becomes her «mother». August turns out to be the parent she never had, and that she so intensely wished for; the maternal figure that will make her feel loved and will even have the strength and courage to face Lily's father (T. Ray), and convince him that the margin is the best place for her to be, the environment where she is going to be loved, respected and educated.

At the same time, and parallel to the bond August and Lily have, attention should be paid to Rosaleen and August's relationship. Rosaleen is Lily's caregiver, and the following quotation from Lerner's Black Women in White America expresses the way she felt when she met the Boatwright sisters:

Disenchantment of Blacks over such liberal tactics, over the limited gains achieved by the civil rights movement and over the wave of killings and violence against Blacks, let to disillusionment with the goal of integration and the methods of nonviolence. Many Blacks, especially the young, now turned away from cooperation with whites and returned to the tradition of self-help, black nationalism and reliance on their own resources. The slogan «Black Power» expressed the new emphasis on autonomy and self-determination gained through struggle (Lerner, 1992: 426).

When Rosaleen first gets to the «pink house» with Lily, she had clear evidence of having been physically abused. Once the Boatwright sisters see her physical condition, their faces turn into a reflection of their pain; pain that is more clearly expressed through May's emotional reaction. Rosaleen becomes, at that precise moment, a reminder of what was the harsh reality outside their margin, their safe haven; a reminder that they could be her, a reminder of the privileged situation they are in, a reminder of what they are fighting for, and a reminder of what they don't want to become. August decides to take both Rosaleen and Lily in, although June opposes to it. August not only becomes Lily's mother figure, but also Rosaleen's. This can be seen in the scene after May's burial, in which she gives Rosaleen the name «July», making her become part of the Boatwright family (August: «From now on, we are going to call you July»). In that scene, we can perceive happiness in Rosaleen's face; August represents both a mother and a sister figure for Rosaleen.

The other relationship that I want to analyze is the one August has with both her sisters, June and May. On the one hand, there is June, the most politically active of the sisters. She has the most balanced relationship with August; she seems not to depend on her as much as May does. She is the one that shows her strength, firmness and independence the most; and the one that seems to be most in touch with the reality going on in the center. She is not only a musician, but also a teacher and an active member of the 
NAACP; she also refuses to marry her long-term boyfriend. The interpretation I make of this fact is that, although she does love him, she struggles with the idea of being part of the patriarchal system that she is able to avoid living in the margin, she resists to being assimilated in the center; somehow, she is trying to hold off the kind of gender oppression and expectations that will come with marriage both from her husband-to-be and society. The moment where we see how she perceives August as that kind of mother figure is when May commits suicide. There, they are both crying, but June leans on her while August holds her, exposing the most fragile side of her sister, showing how much she needs August.

On the other hand, there is May. She is a very special character; she has a very particular and emotional way of taking the terrible and sad events going on around her. She is completely innocent and naïve, and every time she learns about a sad event she breaks down and cries uncontrollably. It is as if she could feel a personal connection to all the pain going on around her. August protects her and tries to make her life happier to compensate all the pain she feels inside. A proof of this is the fact that August painted the house «Caribbean Pink» after May told her that the color «made her wanna dance Spanish flamenco.» August thought: «... if it could lift May's heart, then I guess she ought to live in it.» August is the strength that May needs to keep going, to make sense of the world she lives in.

\section{CONCLUSION}

With The Secret Life of Bees I have approached an African-American female stereotyping that differs from what readers and audiences have traditionally been exposed to. I have tried to prove that through the «Magical Negro» female character (and most of the African-American female characters in the film), the director not only ruptures with the traditional way African-American women have been, and are still represented in the film industry, but also breaks with the usual representation of the «Magical Negro» character. With August Boatwright we have a refreshing character that introduces us to an African-American woman of the 60's in the United States who is not only educated, but also independent, both economically and emotionally.

With this inquiry, I have found facts that help validate the hypotheses presented in the introduction section of this article. First of all, I can state that the fact that the director of this film is not only African-American, but also a female, has directly affected the representation of the character that is the focus of this research. With August Boatwright we witness one of the very few «Magical Negros» that are embodied in a woman; a woman that besides not being castrated, is the representation of the opposition to all the ideas embedded in the endocentric system we live in. This unusual character is contrary not only to the ideas held about African-American women during that period of time, but also to the reality that most of them had to endure. This tendency is also represented in the other two movies Gina Prince-Bythewood directed in the year 2000: Love \& Basketball and Disappearing Acts. Both movies introduce independent African-American women who keep a constant battle against the social oppression and the AfricanAmerican stereotypes of the white patriarchal system, and are actually successful at it. 
Secondly, the link between the sex of the character and its representation can be clearly perceived. With August Boatwright in The Secret Life of Bees we have an image of the «Magical Negro» character that completely differs from the one that has been generally represented in the movie industry. This type of character usually guides or supports the white character, but what we have here is not a simple support relationship. August becomes the mother figure not only for the white female character, but also for the rest of the black female characters in the movie living in the «pink house». She is seen as the linchpin that makes possible living in the safe haven, the «pink house.»

\section{Works Cited}

GoIngs, Kenneth (1994): Mammy and Uncle Mose: Black Collectibles and American Stereotyping, Indianapolis, Indiana University Press, p. XIII, 14, 24.

Hooks, Bell (1984): Feminist Theory: From Margin to Center, $2^{\text {nd }}$ ed., Boston, South End Press, pp. XVI, 3-5.

- (1992): Black Looks: Race and Representation, Boston, South End Press, p. 1.

Joly, Martine (2003): La interpretación de la imagen: Entre memoria, estereotipo y seducción, Barcelona, Paidós, p. 224.

Lerner, Gerda (1992): Black Women in White America: A Documentary History, New York, Vintage Books Edition, p. 426.

Mulvey, Laura (1989): Visual and Other Pleasures, Bloomington and Indianapolis, Indiana University Press, p. 14.

The Secret Life of Bees (2008): Dir. Gina Prince-Bythewood, Perf. Queen Latifah and Dakota Fanning, Los Angeles, Fox Searchlight Pictures, DVD. 